\title{
The Influence of Product Knowledge and Attitude Towards Intention in Mudharabah Funding Products in Sharia Banks in Mataram
}

\section{Baiq Vidia Khairunnisa and Achsania Hendratmi}

Airlangga University, Surabaya, Indonesia

\section{Abstract}

This study aims to determine the effect of product knowledge on attitude and purchase inten-tion for mudharaba financing in Islamic bank in Mataram. This study uses a quantitative approach using the test path analysis. Sources of data in this study using the primary data that is questionnaire. The characteris-tics of the study population are customer of Islamic bank in Mataram who have business and not use mudha-raba financing. The number of samples in this study were 250 respondents. The sampling technique that can be used is probability sampling with random sampling.

Corresponding Author: Baiq Vidia Khairunnisa achsania.hendratmi@feb .unair.ac.id

Received: 10 February 2019 Accepted: 14 March 2019 Published: 28 March 2019

Publishing services provided by Knowledge E

(c) Baiq Vidia Khairunnisa and Achsania Hendratmi. This article is distributed under the terms of the Creative Commons

Attribution License, which permits unrestricted use and redistribution provided that the original author and source are credited.

Selection and Peer-review under the responsibility of the ICIEBP Conference Committee.

\section{S OPEN ACCESS}

Based on the results of the study, it is indicated that product knowledge significantly influences the at-titude, product knowledge significantly influences the purchase intention, and attitudes significantly influence the purchase intention. The suggestions for Islamic Bank in Mataram is to use personal promotionabout mud-haraba financing and increase the service and facilities to improve the contumer intention. The suggestions for further researcher, can be done by adding the level of purchase knowledge and usage knowledge as eksogen-variable and research can be done on other objects in the field of services such as BMT.

Keywords: product knowledge, attitudes, purchase intention of mudharaba financing

\section{Introduction}

\subsection{Background}

Marketing is defined as a social and managerial process, in which individuals and groups obtain what they need and want through the creation and exchange of products and values (Kotler and Armstrong, 2004: 4).

Marketing becomes one of the main activities that need to be done by a company, be it a goods or ser-vice-based company, in an effort to maintain its business survival. To win the competition, a compa-ny must be able to implement the right marketing 
strategy for the product or service they produce. Ap-propriate marketing strategies can be made by un-derstanding consumer behavior (Assael, 1992: 15).

Engel (1994: 4) argues that consumer behavior can be defined as the actions of individuals directly involved in the business in obtaining and using economic services, including the decision-making processes that precedes and determines those actions.

In consumer behavior, there is a set of decision-making processes to determine consumer choice alternatives, in which consumers assess the various alternative options and choose one or more of the necessary alternatives based on particular considerations. Consumer knowledge is an important component affecting the decision-making process (Engel, 1994: 31). When consumers have know-ledge, they will act in a more efficient and more appropriate manner in processing information and be able to recall information about the product better.

Engel, Blackwell, and Miniard (1994: 317) define product knowledge as a collection of various information about the product. Product knowledge includes product category, brand, product terminology or product features, product pricing, and product trust.

According to Brucks quoted from Engel (1995: 332), there are two ways to measure product knowledge based on previous studies, namely Subjective Knowledge and Objective Knowledge. After consumers search for the product information, they begin to assess and evaluate, resulting in a positive at-titude towards the product. Attitudes toward certain behaviors cannot be observed or measured directly, but can be inferred from one's evaluative responses to the attitudes of certain objects according to the consumer's memory.

After attitude of the evaluation of the product knowledge has emerged, then intention in the prod-uct will manifest. With intention, consumers can make purchase decisions after comparison and as-sessment of the product (Fisbein and Ajzein, in Lin and lin, 2007: 124).

The development of Islamic banks in Indonesia began in 1990, after the Workshop on Bank Usury held by the Indonesian Ulema Council (MUI) in West Java, resulting in the birth of the first Islamic bank in Indonesia named Bank Muamalat Indonesia (Antonio, 2001: 25). In the following years, Islamic banks are growing rapidly with the emergence of Sharia Commercial Bank (BUS), Sharia Business Unit (UUS), and BPR Syariah with assets that con-tinue to increase from year to year.

The process of consumer decision-making by ana-lyzing relationship between product knowledge and the intention of purchasing product is put into con-sideration in determining the right marketing strate-gy for companies, including Sharia Banks. Sharia banks as financial institutions have financing prod-ucts with various contracts (akad), one 
of which mudharabah contract. Karim (2010: 204-205) cites the opinion of M. Anwar Ibrahim that mudharabah is a joint partnership between the property of one party and the work of another, in which one party acts as the owner of the capital and entrusts the amount of capital to be managed by a second party, the business owner, for the purpose of creating prof-it.

Mataram as the capital of West Nusa Tenggara Province has the potential to become the target of sharia banks in developing sharia banking products. The Islamic finance industry in West Nusa Tengga-ra, particularly in Mataram, is experiencing rapid growth. Over the past five years, their combined as-sets reached Rp. 144 trillion, while their total financ-ing assets amounted to 1.955 trillion (bi.gi.id). Therefore, this research designated the Bank Syariah in Mataram as the object of research to determine the influence of customer product knowledge on the attitude and intention of using mudharabah financing product.

\subsection{Problem statement}

1. Does product knowledge affect the attitude of using financing mudharabah in sharia banks in Mataram City?

2. Does attitude affect intention in using mudhara-bah financing in sharia bank in Mataram City?

3. Does product knowledge affect the intention in using mudharabahfinancing in sharia banks in Mataram City?

\section{Theoretical Framework and Hypothesis Development}

\subsection{Consumer behaviour}

Engel (1994: 4) argues that consumer behavior can be defined as the actions of individuals directly involved in the business in obtaining and using eco-nomic services, including the decision-making processes that precede and determine those actions. Loudon and Bitta (1993: 6) define consumer beha-vior as a process of decision making and the physi-cal activity of individuals involved in evaluating, obtaining, and using goods and services. 


\subsection{Consumer behavior in an Islamic perspective}

Consumer behavior in Islam should reflect adhe-rents' relationships with God. Every movement in the form of daily shopping is nothing but the ma-nifestation of remembering (zikir) the name of God by not choosing forbidden (haram) goods, not being parsimonious, and not being greedy to survive in both the present world and the hereafter (akhirat) (Muflih, 2006: 4).

Islam sees human need as more than a matter of clothing, food, and housing, because they are only related to worldly businesses. As-Syatibi in Muflih (2006: 66) said that the formulation of human needs in Islam consists of three levels, namely:

1. Dharuriyat, which comprises of religion (din), life (nafs), education ('aql), offspring (nasl), and property (mal).

2. Hajiyat is any complement that supports, streng-thens, and protects the dharuriyat needs.

Tahsiniyat is any addition to the forms of pleasure and aesthetics other than dharuriyat and hajiyat.

\subsection{Decision-making process}

Kotler and Keller (2009: 235) mentioned that the purchase decision process plays an important role in understanding how consumers actually make purchasing decisions. Marketing scholars have com-piled a "phase order model" in the consumer pur-chase decision process.

\subsection{Product knowledge}

Engel, Blackwell, and Miniard (1994: 317) stated that product knowledge is a collection of various in-formation about the product. This knowledge in-cludes product categories, brands, product terminol-ogy, product attributes or features, product prices, and product beliefs. Product knowledge also in-cludes various information that is processed by consumers to obtain a product. Product knowledge also consists of knowledge of where to buy products and when to buy them. When a consumer decides to buy a product, he will decide where he will buy the product and when to buy it. The consumer's decision regarding where to buy the product will be largely determined by his knowledge. Brucks 
(1985) stated, "Product knowledge is based on memories or known knowledge from consumers."

\subsection{Measurement of product knowledge}

Brucks (1985) in Engel (1995: 332) says that product knowledge can be assessed by two indica-tors, namely Objective knowledge and Subjective knowledge.

Objective knowledge are the correct information about the classes of products stored in the consum-ers' long-term memory.

\subsubsection{Product knowledge}

The product knowledge itself is a collection of many different types of information. Product know-ledge includes: Awareness of product categories and brands within product categories, product terminol-ogy, product attributes or attributes, and beliefs about product categories in general and for specific brands.

Belief in this case where there is a belief that a product will provide utilities or benefits. Consumers will pay more attention to products that can generate utility, putting it into consideration in a purchase de-cision. Consumer trust can be formed from the conformity of a product with the principles of sharia.

Product Criteria in the Islamic perspective are:

1. Products in Islam according to Abuznaid (2012) are prohibited to contain the practice of cheating, gambling (maysir), and usury. This is in accordance with the word of God in Al-Maidah (5):4 : "lawful unto you are (all) things good and pure: and what ye have taught your trained hunting animals (to catch) in the manner directed to you by Allah: eat what they catch for you, but pronounce the name of Allah over it: and fear Allah; for Allah is swift in taking account.." (DEPAG RI, 2012)

2. Prophet Muhammad, when trading, always pro-vided information as clear as possible regarding the advantages and disadvantages of the products he sold. Islamic business ethics also requires that accurate information be provided not only to the goods sold but also in terms of their advertising (Abuznaid, 2012).

3. Interest in Islam is expressed as riba. The usage of riba is strictly prohibited in the Qur'an and hadith. The word riba in English is often represented as usury, which in modern use means more than ordinary interest rates or stifl-ing interest rates. 
Nafik (2009: 110) argues that because Islam forbids usury, then banks that op-erate in accordance with sharia should imple-ment a system of profit-sharing.

\subsubsection{Purchase knowledge}

Purchase knowledge includes various pieces of information owned by consumers that are closely re-lated to product acquisition. The basic dimension of purchasing knowledge involves information regard-ing decisions about where the product should be purchased, when purchase should occur, and usage knowledge.

Subjective Knowledge is the level of understand-ing of consumers on a product, which is called self-assessed knowledge. Indicators of subjective know-ledge according to Engel, Blackwell, and miniard (1995: 317) are:

1. The amount of consumer knowledge towards a product

2. The value of consumer knowledge of a product when compared to other consumers

3. How familiar consumers are to a product

When consumers use a product, how comfortable they feel in using/buying products based on consum-er knowledge about a product.

\subsection{Consumer attitude}

Consumer attitude studies the tendency to respond consistently to something liked or disliked to the attention given to an object (Schiffman and Kanuk, 2007: 232). Consumer attitudes are a reflection of the overall evaluation of the association of a brand, product, object, or activity (Hoyer and Maclnnis, 2008: 122).

\subsection{Attitude measurement}

Schiffman and Kanuk (2007: 238) suggested that Attitude toward object model is very suitable for ex-pressing attitudes toward a specific product (or ser-vice) category or brand. Based on this model, con-sumer attitudes toward a specific product or brand of a product is a convincing presence and evaluation of specific functions-beliefs and/or attributes. Accord-ing to Schiffman and Kanuk (2007), there are sever-al indicators that can be used to measure consumer attitudes. 
1. Consumers like the benefits provided by the product or brand.

2. Consumers like the ease of use of the product or brand used.

3. Consumers like the reliability of the product or brand.

4. Consumers like the service of the brand.

5. Consumers like products or brands that portray the consumer's personality. Consumers like the added value of a given product or brand.

\subsection{Purchase intention}

Consumer intention is a form of desire (behavior intention). The desire to behave can be defined as the desire of the consumer to behave in a certain way in order to own, use, and dispose of products or services (Mowen and Minor, 2002: 322).

According to Ferdinand (2002: 129), intention in using services or products can be identified through the following indicators:

1. Transactional intention, namely the tendency of someone to buy a product

2. Referential intention, namely the tendency of someone to reference a product to others.

3. Preferential intention, which is an intention that describes the behavior of someone who has a primary preference for a product. This prefe-rence can only be changed if something happens with the preferred product.

Explorative intention, which portrays the behavior of a person who is always looking for information about the product he is intentioned in and seeking in-formation to support the positive characteristics of the product.

\subsection{Sharia bank}

Sharia bank is a bank that in its activities, either in collecting funds or in the framework of the distribution of funds, provides and imposes rewards on the results on the basis of sharia principles, namely trade and profit-sharing. The main principle of bank operations based on sharia principles is the Islamic law that comes from the Qur'an and Hadith. Bank opera-tions must pay attention to orders and restrictions in the Qur'an and the Sunnah (ways) of Prophet Mu-hammad. Prohibition mainly relates to bank activi-ties which can be classified as riba (usury) (Susilo, 2000). 


\subsection{Mudharabah}

Antonio (2001: 95) quoted al-Syarbasyi's opinion as follows: "Mudharabah is a contract of business between two parties where one (shahibul al-mal) provides all (100\%) of the capital, and the other par-ty becomes the manager. The profit of the business is divided according to the agreement set forth in the contract, while the loss is borne by the owner of the capital as long as the loss is not the result of the manager's negligence." Mudharabah is described also in QS.Al-Maidah verse one.

\subsection{Determination of Mudharabah in Sharia banking}

The concept of mudharabah in sharia banking is usually applied to funding and financing products. On the fund-raising side, mudharabah applies to the following products: (Antonio, 2001: 97)

1. Savings futures, namely savings intended for special purposes, such as savings for pilgrimage, and savings for cattle slaughter (kurban), and so forth.

2. Ordinary and special deposits, special deposits (special investment), where the funds deposited by customers, specifically for certain businesses, such as in murabahah or ijarah only.

Meanwhile, on the financing side, mudharabah ap-plies to:

1. Work capital financing, namely financing in-tended to meet the needs of business funds for the purchase / procurement / provision of elements of goods in the framework of capital turnover. Exam-ples are for the purchase of raw materials or goods to be traded.

2. Special investment, namely the financing pro-vided to meet the needs of business facilities / infra-structure (fixed assets). For example, the purchase of production equipment.

\subsection{Relationship between the product knowledge and attitude}

According to Engel, Blackwell, and Miniard (1995: 316), consumer knowledge consists of infor-mation stored in memory. Marketers in particular are interested in knowing consumer knowledge. Infor-mation held by consumers about the product will greatly affect the consumer pattern. An awareness and image analysis is useful for exploring the nature of product knowledge. 
Consumer knowledge is a key determinant of con-sumer behavior. What consumers buy, where they buy it, and when they buy it will rely on knowledge relevant to the decision. The underlying influences of consumer behavior are environmental influences, individual influences, and psychological influences. In this case, the element of knowledge includes the influence of the individual. Engel, Blackwell, and Miniard (1995: 317) divide consumer knowledge in-to three knowledge categories, namely product knowledge, purchasing knowledge, and knowledge of usage.

\subsection{Relationship between attitude and intention}

Attitude studies the tendency to respond consis-tently to something liked or disliked to the attention given to an object (Schiffman and Kanuk, 2007: 232). Thus, it can be concluded that attitude is the result of the overall evaluation of an association of a product or brand in which the feelings and emotions that form can affect one's lifestyle. A positive atti-tude towards a brand or product can increase con-sumer purchase intention in a product.

\subsection{Relationship between product knowledge and intention}

Lin (2007) says that the level of product know-ledge affects consumer purchase intention. In gener-al, consumers with higher product knowledge have better memory, recognition, analysis, and logical skills than those with lower product knowledge. Consequently, those who think that they have higher product knowledge tend to rely on intrinsic cues in-stead of stereotypes to make an assessment of prod-uct quality as they realize the importance of product information. A similar study was conducted by Ghalandari and Norouzi (2012), who overall stated that product knowledge affects purchase intention in a product.

The research used an analytical model developed from a research by Lin, Nan Hong, \& Lin Bin Shya. 2007 The Effect of Brand Image and Product Know-ledge on Purchase Intention Moderated by Price Discount.

This research used structural equation for endogen-ous intervening variable (Z) as follows:

$$
Z=\gamma X+e
$$

This study also used structural equations for endo-genous variable ( $\mathrm{Y})$ as follows:

$$
Y=\beta Z+\gamma X+e
$$




\section{Research Framework and Hypotheses}

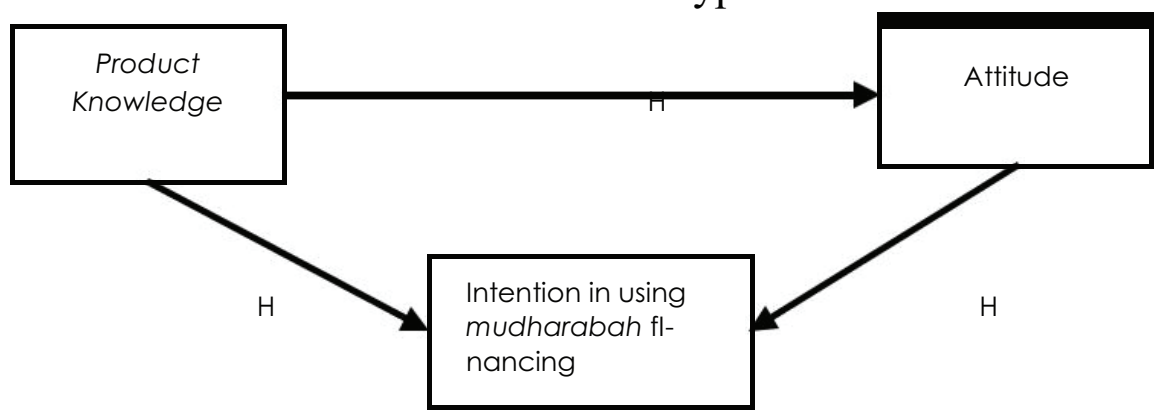

Figure 1: Analysis Model (Source: Author).

Notes:

$\mathrm{Y}=$ Intention to use mudharabah financing productoin sharia banks

$B=$ Path Coefficient from endogenous variables to exogenous variables

$\mathrm{Z}=$ Attitude towards mudharabahfinancing products in sharia banks in Mataram

$\gamma=$ Path Coefficient from exogenous variable to endogenous variable

$$
\begin{gathered}
X=\text { Product knowledge } \\
\text { E = Standard error }
\end{gathered}
$$

The framework of thinking in this study is outlined below.

\section{Research Method}

This study used some research variables, includ-ing: product knowledge as exogenous variable, atti-tudes as endogenous intervention variable, and pur-chaseintention as an endogenous dependent variable. Product knowledge has two indicators, including: subjective knowledge and objective knowledge, consisting of 20 items of questions. Attitude variable consists of five indicators, with five question items. The purchasing intention variable has four indica-tors, namely transactional, referential, preferential, and explorative intentions. The total number of question items for knowledge, attitude, and intention is 29 question items

The reliability test usedCronbach Alpha. In this study, the Cronbach Alpha value was above 0.6 , so this study can be considered reliable. The validity test yields 3 items. 


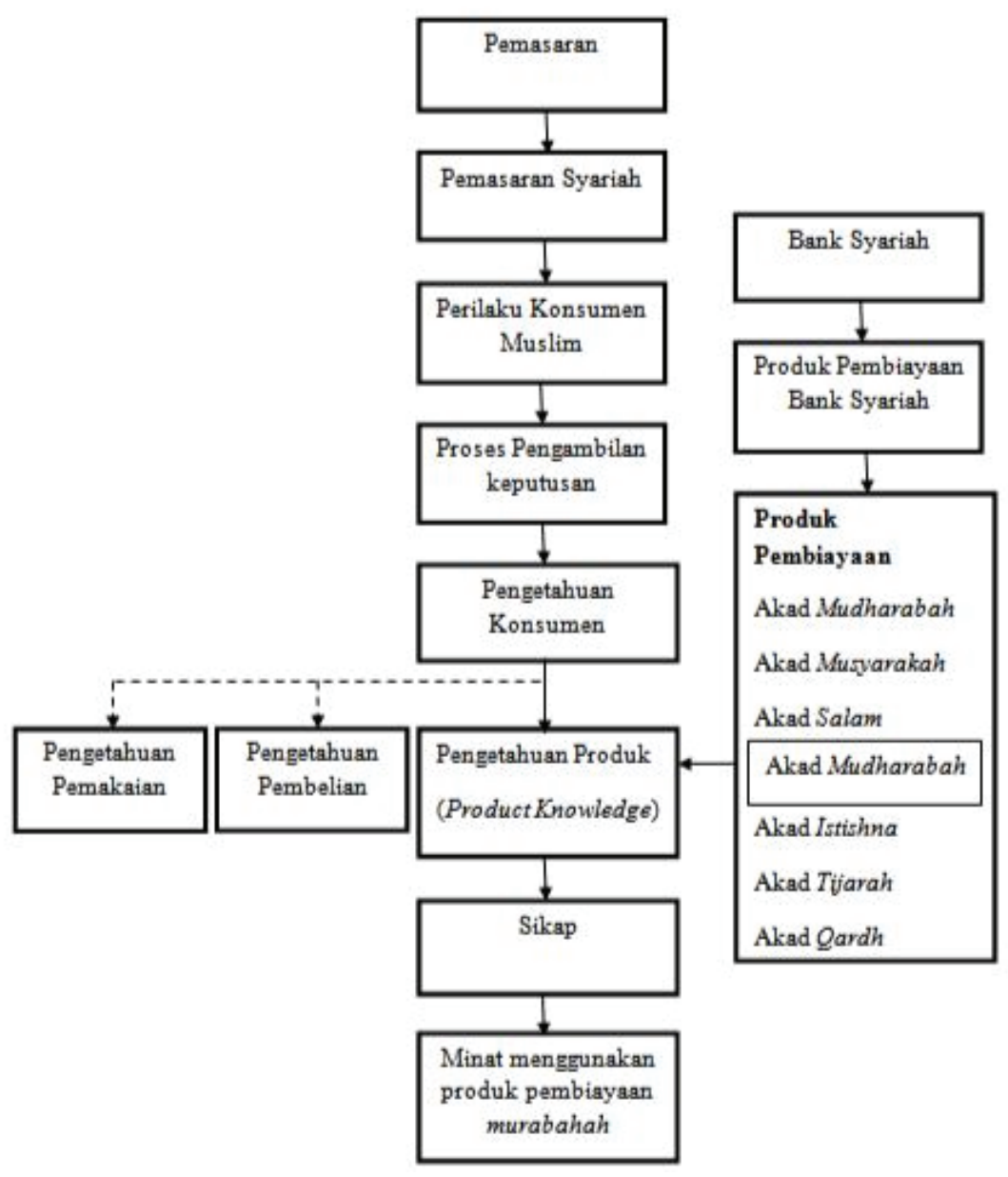

Figure 2: Framework of thinking.

The scale of measurement in this research is or-dinal scale with likert scale model which used four answer, namely: (SS) Strongly agree with a score of 4, (S) Agree with a score of 3, (TS) Disagree with a score of 2, (STS) agree with a score of 1 . The type of data used was primary data obtained through questionnaires that had been filled by respondents and secondary data as a support in the form of cor-porate documents, some of which are supporting da-ta such as journals, documentation photos, internet sources, and literature related to the problems stu-died.

The subjects or population in this study are the customers of sharia banks in Mataram. The cha-racteristics of the sample used were customers of sharia banks in Mataram who own or plan to have business. The population in this study was 250 people.

Sampling technique in this research used the Probability sampling, namely sampling which gives equal opportunity for each element (member) of the population to be elected as a sample member, so the number of samples in this study is 250 respondents of sharia bank customers in Mataram. The number of questionnaires distributed was 
250 questionnaires. The analysis model used to determine the effect waspath analysis using SPSS and Amos programs.

\section{Research Results and Discussion}

Data processing in the testing of path analysis as-sumptions used Amos and interpreted through the following Table:

TABLE 1: Coefficient Values of Influence Paths be-tween Variables.

\begin{tabular}{l|c|c|c|}
\hline \multicolumn{2}{c}{ Variable } & $\begin{array}{c}\text { Direct Path } \\
\text { Coefficient }\end{array}$ & $\begin{array}{c}\text { Indirect Path } \\
\text { Coefficient }\end{array}$ \\
\hline Product knowledge & Consumer Attitude & 0.625 & \\
\hline $\begin{array}{l}\text { Consumer Attitude } \\
\text { Product knowledge }\end{array}$ & Purchase intention & 0.380 \\
\hline $\begin{array}{l}\text { Product Knowledge to Purchase intention through Attitude } \\
\text { Source: Data processing results }\end{array}$ & Purchase intention & 0.394 & \\
\hline
\end{tabular}

The table above can be interpreted as follows:

1. If the product knowledge variable changes, then it will cause a change in consumer attitudes. The positive sign indicates a unidirectional change, that is, if the product knowledge variable in-creases then the consumer's attitude will in-crease, and vice versa, if the variable of product knowledge decreases the consumer attitude will also decrease with a pah coefficient of 0.625 .

2. If the product knowledge variable changes, the purchasing intention will change. The negative sign indicates a change in the opposite direction, which is if the product knowledge variable in-creases then the purchase intention will decrease, and vice versa, if the variable of knowledge of the product decreases then the purchase intention will increase. The path coefficient value was -0.009 . If the consumer's attitude towards variable changes, then the purchase intention will change. The positive sign indicates a unidirectional change, that is if the consumer attitudinal varia-ble increases then the purchase intention will in-crease, and vice versa, if the consumer attitude variable decreases the purchase intention will al-so decrease. The path coefficient value was 0.380 .

Coefficient of determination is a coefficient that shows the magnitude of influence or contribution of an exogenous variable to and endogenous interven-ing variable and exogenous and endogenous va-riables toward endogenous variables. The following are the test results that show the coefficient of de-termination: 
TABLE 2: Coefficient of Determination Value.

\section{Variable}

Product knowledge to Attitude

Product knowledge to attitude towards intention
R2

0.359

0.360

The following is an explanation of Table 2 above:

1. The amount of attitude change caused by the knowledge of the product was 0.359 or $35.9 \%$. In other words, the effect of product knowledge on attitude was $35.9 \%$.

2. The amount of intention change caused by prod-uct knowledge and attitude was 0.360 or $36 \%$. In other words, the effect of product knowledge and attitudes toward intention was $36 \%$.

The next step is proving the hypotheses. The com-plete results of the hypothesis test can be seen in Table 3.

TABLE 3: Results of Hypothesis Test on Direct Effect.

Variable
Product knowledge $\rightarrow$ Consumer
Attitude
Consumer Attitude $\rightarrow$ Purchase
intention
Product knowledge $\rightarrow$ Purchase
intention

\begin{tabular}{|c|c|}
\hline CR count & Sig. \\
\hline 11.601 & 0.000 \\
\hline 5.211 & 0.000 \\
\hline 5.183 & 0.000 \\
\hline
\end{tabular}

Notes

Significant

Significant

Significant

Table 3 above can be explained as follows:

1. The value of $C R$ count of product knowledge va-riable to attitude was 11.605 . The level of signi-ficance was 0.000 . This value is less than 0.05 . Since the significance level is less than 0.05 , the product knowledge affects attitudes. Thus, the research hypothesis is accepted.

2. The value of $C R$ count of consumer attitude va-riable to purchase intention was 5.211. The level of significance was 0.000 . This value is less than 0.05. Because of this significance level is less than 0.05 , then consumer attitude affects the purchase intention. Thus, the research hypothesis is accepted.

3. The value of $C R$ count of product knowledge va-riable to purchase intentionwas 5.183. The level of significance was 0.000 . This value is less than 0.05 . Since the significance level is less than 0.05 , the product knowledge affects attitudes. 
Thus, the research hypothesis is accepted. The direct influence of product knowledge on atti-tude and attitude towards purchase intention in-dicates that product knowledge indirectly influ-ences purchase intention through attitude.

The figure of the indirect effects of product knowledge on intention through attitude is described on the next page:

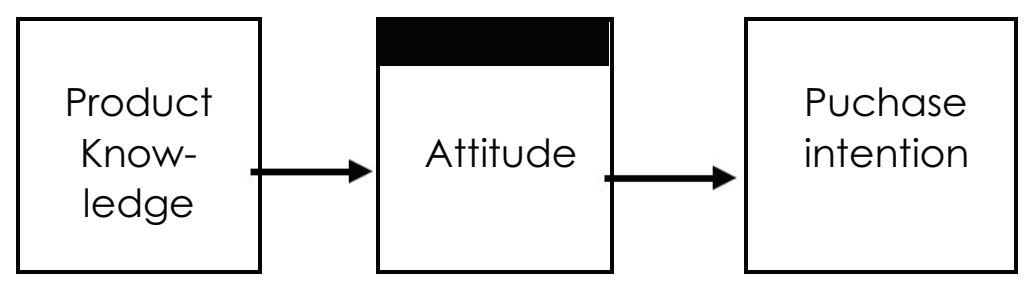

Figure 3: Indirect Path Coefficient.

Figure 3 shows the indirect effect of product knowledge on purchase intention through attitude. The value of the indirect path coefficient was 0.237 . Value is derived from the multiplication of the direct influence of product knowledge on attitude and atti-tude towards intention. Thus, the indirect coefficient value of product knowledge on intention through at-titude was $0.625 \times 0.380=0.237$. This value is greater than the direct path coefficient (-0.009). With this result, product knowledge indirectly influences intention through attitude. Thus, the research hypo-thesis is accepted.

\section{Conclusion}

Based on the results of data processing using path analysis, the following conclusions may be drawn:

1. Product knowledge significantly affects consum-er attitude. With this result, the research hypo-thesis is accepted.

2. Attitude significantly influences purchase inten-tion. With this result, the research hypothesis is accepted.

Product knowledge significantly affects purchase in-tention. With this result, the research hypothesis is accepted.

\section{References}

[1] Abuznaid, Samir. 2012. Islamic Marketing: Addressing The Muslim Market. An-Najah Univ. J. Res. (Humanities). Vol. 26(6) 
[2] Al Qur’an dan Terjemahnya. 2012. Departemen Agama Republik Indonesia.

[3] Antonio, Muhammad Syafi'i. 2001. Bank Syariah, Dari Teori Ke Praktek. Jakarta: Gema Insani.

[4] Assael, H. 1992. Consumer Behavior and Marketing Action. New York: PWS-KENT Publishing Company.

[5] Engel, F. James; Roger D. Blackwell; Paul W. Mi-niard. 1994. Perilaku Konsumen. Jakarta: Bi-narupa Aksara.

[6] Ferdinand, Augusty. 2002. Metode Penelitian Manajemen. Semarang: Badan Penerbit Universitas Diponogoro

[7] Karim, Adiwarman A. 2010. Bank Is/am Analisis Fiqh dan Keuangan. Edisi ke Empat. Jakarta: PT. Raja Grafindo Persada.

[8] Kotler, Philip dan Gerry Amstrong. 2004. Principles of Marketing. Tenth Edition. New Jersey. Pren-tice Hall Inc.

[9] Kotler, Philip dan Kevin Lane Keller. 2009. Ma-najemen Pemasaran. Edisi 12, Jilid 1. Jakarta: Airlangga

[10] Lin. N.H and Lin. B.S. 2007. The effect Of brand image and product knowledge on purchase in-tention moderated by price discount. Journal of international management studies.

[11] Loudon, David L. Dan Albert J. Della. 1993. Costu-mer Behaviour: Concept and Applications. Singapore: McGraw Hill Book Company.

[12] Mowen, John C dan Minor. 2002. Perilaku Konsu-men. Edisi ke 5. Jilid 2. Jakarta: Airlangga

[13] Muflih. 2006. Perilaku Konsumen Muslim Dalam Persfektif Ekonomi Islam. Edisi pertama. Ja-karta: Raja Grafindo Persada.

[14] Schiffman, Leon dan Leslee L. Kanuk. 2004. Cos-tumer Behavior. Eight Edition. New Jersey. Pearson Prentice Hall Inc.

[15] www.bi.go.id diakses pada tanggal 3 Maret 2014 